\title{
PARENTAL INVOLVEMENT AND READING CULTURE AMONG SECONDARY SCHOOL STUDENTS CASE OF INTERNATIONAL SCHOOLS
}

\author{
Otieno O. Davis ${ }^{1 i}$, \\ Andala Hesbon ${ }^{2}$ \\ ${ }^{1}$ Student, \\ Mount Kenya University, \\ Rwanda \\ ${ }^{2}$ Lecturer PhD, \\ School of Education, \\ Mount Kenya University, \\ Rwanda
}

\begin{abstract}
:
Poor culture of reading among Rwanda students is a perennial problem. This study sought to investigate the relationship between parental involvement and reading culture among secondary school students. Specifically, the study sought to identify parental involvement practices in promoting reading culture among students in international secondary schools, to identify reading culture practices among students in international secondary schools and to determine the influence of parental involvement on reading culture among students in international secondary schools. Descriptive and correlational research designs were adopted. Primary data was collected using questionnaires and interview guide. The population size was 3557 and a sample size of 360 was computed which comprised of teachers, parents and students. The study utilized purposive, stratified proportional and simple random sampling techniques. Data was processed using IBM SPSS software version 21 in addition to Excel and presented in tabula and graphic forms. Computation of percentages and frequencies formed the basis of descriptive analysis. The study findings indicated that $41 \%$ and above of parents, teachers and children supported that parents are involved in various learning practices which includes joint reading, donating books and teaching aids to school, going through students' homework, buying recommended books to the children, encouraging technology use in reading and offering reading incentives to the children. Additionally, findings did indicate that between $36 \%$ to $51 \%$, 39\% to $61 \%$ and $41 \%$ to $57 \%$ of teachers, parents and students respectively agreed that students engage in various reading culture practices including having favorite story books, spending free time reading, love for reading, talking about books they have read, creative and writes something on what they
\end{abstract}

${ }^{i}$ Correspondence email: davisvyosa@gmail.com 
have read and making consultations from teachers and parents for clarifications. Moreover, the findings indicated that there is still a great percentage of parents who don't engage themselves on students learning matters supported by $17 \%-40 \%$ of respondents and also a greater percentage of students having poor reading culture in secondary schools supported by at most $45 \%$ of respondents. correlation finings indicated a Pearson correlation coefficient of 0.650 which positive and significant whereas regression finings indicated $\mathrm{R}$ squared of $54.7 \%$ and beta coefficient of 0.119 with $\mathrm{p}$ value of 0.025 for parental involvement. The study concluded that there is a moderate involvement of parents in the learning process of their children, good reading culture is practiced to a moderate extent by secondary school students in Rwanda and there is positive significant influence of parental involvement on reading culture among secondary school students. This study recommends parents to engage in various activities aimed at promoting the reading culture and performance of their children. Schools to organize workshops to enlighten the parents on the need to engage in various supports to promote their students reading culture.

Keywords: parental involvement, reading culture, international school

\section{Introduction}

\subsection{Background of the study}

Foundation in reading forms the back born of education system and teachers across the globe struggles to ensure that students develop interest in this basic learning skill. Educators encourage students to read widely so as to enhance their comprehension skills, for general knowledge, cultural awareness and expand their vocabulary. With the increasing number of students in schools, there is need to form a wide team of education stakeholders to realize positive improvement in academic performance. Moreover, education stakeholders must actively participate in addressing education issues rather than shifting the burden to the teachers only. Parents need to understand that they are the first teachers of their children and not educationists (Dunn, 2012). According to (Epstein, 1995), the benefits of active parental involvement range from development of lively school climate, curriculum improvement, enhances teachers' motivation and lastly own parents' skills development on child education.

According to OECD (2012), responsible parents in education matters helps their children to gain more in terms of development of basic skills in areas like language, planning activities and target setting among others which not only helpful to the student in the education life but also life beyond schooling. Parents contribute in leadership sharing through involvement in education matters by working closely with the administrators and teachers to boost children' performance (Epstein (2009). The various discussions support the idea of parental involvement on education process for sustained students' academic performance. The question remains on the extent of implementing this idea. Research has shown that pleasure reading may have a greater impact on 
student's overall performance (Pearson, 2015). Reading is the foundation skill for all school-based learning, academic and occupational success since it increases learners' level of confidence and boost self-esteem and motivation to learn.

Kachala (2007) in Malawi further asserts that reading is a continuous process that starts from childhood and develops to adulthood. This can promote the notion that a reading nation is a wealthy nation. A reading population is often characterized by possession of adequate skills, economic empowerment, improved living standards and finally rapid economic development. According to Batambuze (2005), the possibility of reading culture development in the society calls for mass acceptance by the society members that reading exist in all life aspects and goes beyond just school or work.

A document of the education Ministry stresses the need to convert Rwanda's traditional oral culture into booklets in order to promote the reading culture among youth and adults which is cited as a challenge among students in Rwanda (Ruterana, 2012). The document further recognizes the importance of loud reading and storytelling as some of the tools of literacy acquisition that should be practiced by the youth (Mukandekezi, 2005). The Author proceeds to add that these tools should be applied at a tender age in nursery and primary schools in order to develop reading culture among the youth hence increasing literacy which ultimately leads to general improved education standards among Rwandans.

Rwanda's Education Sector Strategic Plan 2013-2018 identifies the need to improve quality of education and training and strengthen the relevance of education and training to meet the labour market demand. This quality of education relates to all dimensions of a child's social, physical and emotional development, which can be measured by their academic achievement. To achieve this reading plays an integral role in developing literacy and critical thinking.

Parental involvement plays an important role in influencing children interest and perception on different aspects of life. Parents are the children's first teacher and home is their first school. Research has shown that children learn more before they enter school through observation. Learning from home and parents does continues well even after children have entered school improves children's attitude towards reading hence parental input in terms of involvement is very essential. The element of attitude plays a role in reading, according to Mckenna, Kear, Ellsworth (1995) "even for the fluent reader, poor attitude may occasion a choice not to read when other options exist, a condition now generally known as illiteracy."

\subsection{Statement of the problem}

Reading is an important skill that has to be acquired and most curricula and schools set a considerable amount of time and effort to develop this skill. Though reading is enjoyable and easy to some students, it is still a challenge to others (Gilbert, 2016). The reading culture among Rwandan population is still noted to be low. According to the general census data (Ministry of Finance, 2007), the illiteracy level of people of 15 years and above was $47.6 \%$ i.e. they cannot read and write. This scenario was noted to slow 
down the implementation of public policies (MINECOFIN, 2007). Lack of awareness of the advantages associated with reading has been identified as one of the factors for lack of reading interest (Ruterana, 2012). Surprisingly, International schools within Kigali which are usually well resourced with libraries of different books that might interest different levels of learners are also grappling with poor reading culture (New times, $10^{\text {th }}$ June 2015).

Parents play a significant role on students learning process and act as the first educators of children. According to Ndileleni (2014), parents are the first teachers of a child and the first school for a child is home. Therefore, parents must bestow love for learning in the child and offer guidance to the child to persevere on his or her own. Ndileleni (2014) further notes that most parents associate reading to school work and may only encourage their children to read for the sake of academic performance, failing to recognize the importance of encouraging pleasure reading and independent reading habit. Parents therefore downplay their role in impacting reading culture. This scenario necessitated the researcher to investigate the influence of parental involvement on reading culture among secondary school students taking a case of international schools.

\subsection{Objectives of the study}

1) To identify parental involvement practices in promoting reading culture among students in international secondary schools.

2) To identify reading culture practices among students in international secondary schools.

3) To determine the influence of parental involvement on reading culture among students in international secondary schools.

\subsection{Research questions}

1) How are parents involved in promoting reading culture among students in international secondary schools?

2) To what extent is reading culture practiced among students in international secondary schools?

3) How does parental involvement influence reading culture among students international secondary schools?

\section{Literature review}

\subsection{Parental involvement and benefits}

Chueng and Pomerantz (2012) perceives Parental involvement as involves parent's active commitment and participation to the school activities and to his or her child. Parents are the first teachers of children and therefore they impact greatly to children's reading culture.

When children acquire knowledge at early stage of their lives it contributes a lot to their future lives. (Whaley, 2017). Through reading books, children develop knowledge and morale to explore places, events and experiences as they grow. (Deal \& Peterson, 
2016). The attitude and support willingness on the side of the parent is very fundamental to boosting the literacy of the child regardless of social class, education level and size of the family. (Benner, Boyle \& Sadler, 2016). Therefore, for a child's literacy development, there is need for the parent to develop a positive attitude towards reading and support the child on the same for the betterment of the child's future life. Active support of the child's learning at home by the parent comes with benefits such as improved writing skills, language boost and reading achievement. (Casey et al., 2018). According to Blades (2015), a child who develops reading interest at early ages repeats the same at later ages. Reading together with the children at home enables them to develop social interaction skills and the parents gets to know more about the child, weaknesses and strengths so that corrective action can be taken for the child's benefit in terms of improved literacy skills, enhanced reading culture and overall growth. Active participation of parents to their child's learning at home also enables the child to develop rapidly a sense of focus in life, rapid maturity of the child in terms of how he or she reasons out issues and ability to tackle challenges. This is boosted by the fact that continuous engagement in reading expands a child's knowledge and he or she is able to discover more on life matters, hence boosting literacy. Moreover, early exposure of the child to books gives him or her a competitive edge in terms of being ahead of the peers at school (Gruwel, 2018). To stress on further, Whaley (2017) in his studies on parental involvement concluded that parental interest in a child's education contributes greatly to the child's academic and nonacademic achievement in his or her teens.

\subsection{Barriers of parental involvement}

While a consensus exists on benefits of parental involvement in student learning, engaging parents on their children' education can result in struggle (Shiffman, 2011). However, according to Larocque et al (2011), parental involvement contributes greatly to student attendance, higher scores in math and reading, higher graduation rates and less retention of grades and therefore the need to recognize strategies to improve engagement is imperative. Researchers namely Bartel, 2010; DePlanty, Coulter-Kern \& Duchane, 2007; Dobson, 2001; Hornby G. \& Lafaele R, 2011; Larocque, Kleiman, \& Darling, 2011; Vellymalay S.K, 2012) identified and categorized numerous barriers to increasing parental involvement: environmental factors, parental perceptions, and knowledge.

\subsection{Environmental factors}

Environmental factors contributing to lack of parental involvement include socioeconomic status (SES), level of education, marital status, number of children, gender, and ethnicity. According to Vellymalay S.K (2012) and Bartel (2010), one of the most influential factors was parents' levels of SES. Parents from lower SES were less likely to engage in their children's academic activities than parents from middle and high SES. Factors that frequently contributed to parents' low SES included limited education level, single parent, and number of children in the home (Hornby G. \& Lafele R, 2011). Dobson (2001) noted the changing role of mothers as more women sought careers outside home 
resulted in less availability for involvement in their children's academics and extracurricular activities. Furthermore, changing demographics brought a variety of cultures to schools' student bodies, while the majority of the teachers' demographics remained white and middle SES (Larocque, Kleiman, \& Darling, 2011). The changing diversity of the student bodies created barriers and misunderstandings of differing customs.

\subsection{Parental perception and knowledge}

Another contributing factor affecting the level of parental involvement was parents' perceptions about school (Hornby G. \& Lafaele R, 2011). Some of those perceptions included: a perceived lack of effort from the school or teacher, an environment that seemed unwelcoming, a lack of parent confidence pertaining to the benefits of participation, or negative personal experiences. Whitaker M \& Hoover-Dempsey (2013) agreed that some parents tended to have negative perceptions about schools and their own role in involvement. The power of creating a welcoming school environment generated the difference in the amount of parental involvement. Moreover, De Planty et al. (2007) identified a need to educate parents about the benefits and the methods of involving themselves in their child's academic career.

\subsection{Extracurricular activities}

In addition to parental involvement, another stimulus to motivate reading engagement for elementary students is participation in extracurricular reading programs. According to Stephen W. (2012), after-school programs often create a safe and supervised avenue for children with the added benefit of academic support. Fiore C. \& Roman S. (2010) studied the benefits of summer and school-year reading programs offered by public libraries. Report indicated that students spending time in library during summer reading performs better than those who only depends on school year reading. Furthermore, participation in a library reading program can increase students' motivation to read, build confidence in their reading abilities, and assist in the development of a positive attitude toward reading.

\subsection{Private tutoring}

Private tutoring is another method used to increase reading engagement (Dang A.H \& Rogers F.H, 2008). After the passage of 2001 Act of No Child Left Behind, tutoring industry increased from a five-billion-dollar industry to an eight-billion-dollar industry (Nelson-Royes, 2013). The one-on-one setting with a tutor afforded more individualized instruction directly tailored to students' needs because "every student has the ability to learn, but some students have different learning styles" (Nelson-Royes \& Reglin, 2011, p. 112).

\subsection{Reading culture}

In the modern society reading is very critical and contributes greatly to the participation of an individual in societal matters. As Fredrick O (2011) puts it, reading is the process 
involving cognitive processing of information in a written form. In other words, reading involves extracting a meaning from a written text. According to Monica, Francis and Mildred (2015), Reading has a number of benefits ranging from enriching the quality of life, boosting cultural heritage, empowers and integrates people. Additionally, reading expounds one's comprehension skills, human development and it enhances critical thinking in a person.

Developing a reading culture is paramount to the achievement of reading benefits highlighted above. Reading culture is culture that encourages continuous love for reading and its transmission from one generation to another. A society that has a strong reading culture is a society full of knowledge and skills resources and is in the right track for development (Okundu, 2005). Reading culture should be encouraged right from childhood since it's a progressive process hence the culture should be imparted on children for them to be better readers as they grow (Okundu, 2005).

Good reading culture demands students to have motivation and love for reading widely various resources, they should be able to share amongst themselves and with the teachers and parents what they have read, they should be able to have their favorite story books and apply appropriately what they have read (Mudaki, 2016). Reading should not just be for leisure as sometimes perceive rather it meant to widen a person's level of articulation and approach to issues or problems. It's on this basis that someone is able to develop knowledge and skills and through reading and able to apply what he or she has read. Children are the future leaders of a society and through reading they are able to develop knowledge and skills to tackle societal problems. Therefore, for students to advance their reading culture, they should be having their favorite story books and should love reading and apply and share what they have read.

Smooth reading process requires a range of resources with the most important resource being books, technology and reading infrastructure like library. Books can be in hard copies stocked in shelves in the libraries where students are able access easily, e books which offers online reading, audio books among others (Monica et al, 2015). Technology has made it easy to access reading materials online and this makes the students to develop a wide knowledge even beyond their country borders. Libraries are reading infrastructures where reading materials are kept and can be accessed by readers easily. Through libraries students are able to get a variety of reading materials in addition to also offering a favorable atmosphere for reading.

Good Reading culture has of late deteriorated among students as reported by previous researchers' such as Mudaki (2016), Evans W., (2018), Monica et al, (2015) among others. Monica et al (2015) points out that students' performance in application questions in national exams in Kenya has been poor due to poor reading culture which has limited the knowledge and thinking capacity of students hence not able to tackle application questions. Additionally, the paper argues that students nowadays read to pass exams and not to develop knowledge. This scenario is extended to university students who depend on handouts from lecturers and cannot create time to research on their own through reading (Monica et al, 2015). Ruterana (2012) points out that lack of 
reading materials, colonial education system, infrastructure and use of common language Kinyarwanda has greatly led to poor reading culture among students in Rwanda.

\subsection{Empirical literature on parental involvement and reading culture}

Lara L. and Saracostti M. (2019) conducted a study in Chille to determine the effect of parental involvement on children academic achievement in Chille. The study used primary data collected from parents, teachers and students. Parental involvement was grouped into five categories including parental involvement at school, at home, children invitation, teacher invitation and general school invitation. The parental practices focused on parent reading together and doing homework with the child, parents attending meetings and special events at school, child telling the parent to talk with teacher and requesting for supervision, teachers requesting parents to go through student's homework, and the school contacting the parent in case of a problem with the child at school among others. The results showed that parental involvement was practiced at medium level, high level and low level with respective percentages as $45.3 \%$, $28.9 \%$ and $25.3 \%$ respectively. Additionally, parental involvement was found to have a strong positive significant effect on students' academic achievement.

Mudaki (2016) carried a study in Kenya to determine the influence of parental involvement on performance of children in Kiswahili reading comprehension. The study used primary data and targeted parents, teachers and pupils. The study results revealed that parental involvement is very essential to students reading success and the author recommended that more libraries to be set and be furnished with more books for reading in addition to organizing workshops and seminars for parents to boost their knowledge on parental activities as pertains to children's learning. These findings and recommendations were also supported by Muigai (2018).

Ruterana (2012) in his study on how to enhance reading culture in Rwanda found that poor reading culture in Rwanda is attributed to several factors such as colonial education system, inadequate reading materials, reliance on common mother tongue language Kinyarwanda and reliance on verbal communication. The author went ahead to say that its only in books where you can hide information from Rwandans and if you want something to be known by Rwandans then only whispering will make you through. The study recommended that more national libraries should be constructed across the country and strict rules should be set in schools to reduce the use of common language of Kinyarwanda in school vicinity.

A study by Monica et al. (2015) in Kenya on possible causes of poor reading culture among students in secondary schools in Siaya County cited limited resources and nonparental participation on learning process as some of the causes of poor reading culture among students. The study recommended that parents to actively participate in the learning process by engaging children at home on learning activities in addition to setting up computer labs in schools with full internet to encourage reading among students.

Evans W. (2018) conducted a study in Tanzania to investigate the reading culture among students of higher learning institutions. The study revealed that too much 
assignments in schools, lack of internet and family responsibilities hinders their reading habits. Among the recommendations of the study included need to sensitize the parents on the importance of education so that they should not give too much family responsibilities to their children and always support them back home in their learning process by creating a good leaning environment for their children

Felix (2017) conducted a study in Nigeria on parental engagement with schools and students. According to the findings there was poor engagement of parents with students and schools and this according to the Author could affect the students' academic performance. The study concluded that collaboration between parents, teachers and students is key for students' academic excellence. The study recommended that parents should be more active in extending school activities at home and create good learning environment for their children back home. This will go a long way in boosting their performance academically.

Juma C. \& Mpoki M. (2012) investigated the contribution of parental support to student's ability to acquire numeracy and literacy skills in Tanzania. The findings revealed mixed reactions in families concerning support for the child's numeracy and literacy skills development. Some families could not support their children skills development due to financial problems, poor home environment among other reasons. The study recommended that policies should be formulated that strengthen the ties between the teachers, parents and the community to enhance skills development among children.

\subsection{Research gap identification}

The literature reviewed has established that there is significant impact of parental involvement on literacy and school academics and also highlighted some causes of poor reading culture though most of these studies have been done in other countries. Few studies exist in Rwanda on reading culture for example Ruterana (2012) only looked at the causes of poor reading culture in Rwanda but did not explore on parental involvement as one of the causes of poor reading culture. Moreover, there is no single study that has been carried out in Rwanda on parental involvement and reading culture. Therefore, understanding the relationship between parental involvement and reading culture is fundamental in directing education policy and progress. Two gaps can be identified from the review of the empirical literature. First, parental involvement correlation with reading culture has not been fully explored in most African countries Rwanda included hence the need for this study. Secondly, most literature concerning the concepts of this study are from other countries not international schools in Rwanda hence need for this study.

\subsection{The School-to-Home Transmission Model}

This model stresses the role of the parents in extending the school values on the child at home to ensure improved performance of the child. (Agustinho, 2012). Teachers also have a duty to identify the relevant values outside the school that supports the success of the 
school. Parents needs to ensure that the home environment is conducive enough to support child's learning and boost a child's performance both academically and socially. It is a belief of the schools that frequent interactions between them and the parents and community members leads to extension of cultural values like knowing, writing and talking even at home by parents. Failure by parents to instill cultural values into their children results into lack of good interaction and success in the society. (Felix, 2017). This model recognizes that parents play a critical role in influencing the children's academic performance and stresses the need for the school and the parents to work together towards improving children's performance. Parents are therefore required to support the school policies and guidelines in place in addition to encouraging the children to work hard to guarantee good performance. According to Mamta et al (2018), schools must provide a suitable climate that accommodates both parents and students' social skills. Despite the superiority of the model, it also exhibits some flaws. These include difficulty in differentiating the roles of teachers and parents in formal education, illiteracy of some parents, some parents may not have enough time to parental involvement activities due to other reasons like sickness, inadequate funds and so on and lastly. This model is relevant to this study since parental involvement is key towards promoting the school values at home of which good reading culture act as an example. The efforts of developing a reading culture on students should not only be significant in the school environment but also at home where parents are the key players and therefore should be on the fore front to ensure that it also extended at home.

\section{Research methodology}

\subsection{Research design}

Research design is the guiding structure of conducting research, Kothari (2008). Research design incorporates the collection of data and analysis in order to achieve research objectives. Descriptive and correlational designs were adopted in this study. In descriptive research, the description of phenomenal behavior overtime is done based on the observations so that the existence or non-existence of relationship between the variables can be detected. In order to identify the various forms of parental involvement and reading culture practices, the researcher adopted descriptive design since it describes the situation or a phenomenon as it is. Correlational design aims to measure the correlation between two or more variables. The study adopted correlational design to determine the association between parental involvement and reading culture among secondary school students.

\subsection{Target population}

Head teachers, languages teachers, parents and learners in the five international schools are targeted in this study which adds up to 3557 individuals. 


\begin{tabular}{|l|c|c|c|c|c|}
\hline \multicolumn{9}{c}{ Table 1: Population Frame } \\
\hline School & Head teacher & Language teachers & Parents & Learners & Total \\
\hline Green Hills & 1 & 7 & 487 & 1033 & 1587 \\
\hline Acorns & 1 & 8 & 32 & 47 & 88 \\
\hline International School of Kigali & 1 & 32 & 196 & 503 & 732 \\
\hline Wellsprings & 1 & 29 & 308 & 459 & 797 \\
\hline St. Paul International School & 1 & 8 & 98 & 246 & 353 \\
\hline Total & $\mathbf{5}$ & $\mathbf{1 4 3}$ & $\mathbf{1 1 2 1}$ & $\mathbf{2 2 8 8}$ & $\mathbf{3 5 5 7}$ \\
\hline
\end{tabular}

Source: Schools' records, 2020.

\subsubsection{Sample size and sampling techniques}

The sample size was 360 computed using Yamane's Formula with an error margin of 0.05 as shown below.

$$
\mathrm{n}=\frac{N}{\left(1+N e^{2}\right)}
$$

where,

$\mathrm{n}=$ sample size

$\mathrm{N}=$ total population

$\mathrm{e}=$ margin of error

$\mathrm{N}=3557$

$\mathrm{e}=0.05$

$\mathrm{n}=$ ?

Therefore, $n=\frac{3557}{1+3557(0.05)^{2}} \cong 360$ respondents

Table 2: Sample Frame

\begin{tabular}{|l|c|c|c|c|c|}
\hline School & Head teacher & Language teachers & Parents & Learners & total \\
\hline Green Hills & 1 & 7 & 49 & 103 & 160 \\
\hline Acorns & 1 & 1 & 3 & 4 & 9 \\
\hline International School of Kigali & 1 & 3 & 19 & 51 & 74 \\
\hline Wellsprings & 1 & 3 & 31 & 46 & 81 \\
\hline St. Paul International School & 1 & 1 & 10 & 24 & 36 \\
\hline Total & $\mathbf{5}$ & $\mathbf{1 5}$ & $\mathbf{1 1 2}$ & $\mathbf{2 2 8}$ & $\mathbf{3 6 0}$ \\
\hline
\end{tabular}

Source: Researcher, 2021.

Purposive, stratified and random sampling techniques was utilized in this study. Purposive sampling was applied in selecting the five international schools which offers secondary curriculum. The study involves parental involvement and reading culture among secondary school students. These schools were therefore deemed fit in providing the right information regarding the study topic. The number of respondents to be selected in each school was computed proportionately. In each school the respondents were grouped into 4 strata these are head teacher, language teachers, parents and learners. The 
respondents to be selected in each stratum was based on proportional weights of each stratum. After determining the number of respondents to be selected in each stratum the researcher chose respondents randomly within each stratum hence random sampling.

\subsection{Data collection and procedure}

Primary data was utilized to analyze relationship between parental involvement and reading culture of secondary school students. Targeted respondents are head teachers, language teachers, parents and learners in the five schools. Data was collected using two data collection instruments these are Questionnaires and interview guides. Open and closed questionnaires were used since they are easily coded hence allows easy quantitative analysis and they are easy to administer hence saves time (Beatrice, 2019). Interview guides was used to collect data from head teachers due to its suitability in providing the respondent room to give more information on the focus area. The data was collected online using google forms among students, language teachers and parents while data collection among head teachers was done through online interview using Microsoft teams. This was necessary due to covid-19 pandemic which limited face to face contact.

\subsection{Data analysis}

Coding of the data collected was done before entering in IBM SPSS version 21 for analysis. The techniques that were utilized in presenting the findings included tables and graphics. Percentages and frequency techniques were adopted in descriptive analysis while correlation and regression techniques were used in inferential analysis. The inferential analysis enabled the researcher to ascertain the association between parental involvement and reading culture and determine the influence of parental involvement on reading culture. The following linear model was used.

$\mathrm{Y}=\mathrm{b}_{0}+\mathrm{d}_{1} \mathrm{~V}_{1}+\varepsilon \mathrm{I}$,

Where

$Y$ denotes reading culture,

$\mathrm{V}$ is parental involvement and $\varepsilon_{\mathrm{I}}$ is error term and

$b_{\circ}$ and $d_{1}$ are constants. 


\section{Research Findings and Discussion}

\subsection{Descriptive findings}

This study was based on parental involvement and students reading culture. The study objectives focused on identifying parental involvement practices and reading culture practices in secondary schools in Rwanda in addition to determining the influence of parental involvement on students reading culture. This subsection therefore presents the descriptive findings regarding the study objectives.

\subsubsection{Parental involvement practices}

The researcher sought opinion from students, parents, teachers and head teachers to identify the various parental involvement practices among the secondary school parents in the selected schools for this study. Parents are in better position to give appropriate view since they are the once whose involvement in students learning forms the main focus of this study. Additionally, students' perception is important since they are the beneficiaries of parental involvement therefore able to know the extent to which they receive parental guidance and support in their learning process. Teachers and head teachers also have some idea on parental involvement since they interact with students and parents more often in various activities. The level of agreement of respondents regarding the various statements on parental involvement was assessed on a scale of 1 to 5 where 1, 2, 3, 4 and 5 represented strongly disagree, disagree, neutral, agree and strongly agree respectively.

\subsubsection{Parents perception on parental involvement practices}

The researcher sought opinion of 15 parents from the five selected schools regarding parental involvement on students learning process. This was assessed in a scale of 1 to 5 with strongly disagree on one end and strongly agree on another end. The following table summarizes the results.

Table 3: Parents Perception on Parental Involvement Practices

\begin{tabular}{|l|c|c|c|c|c|}
\hline Parental involvement & SD & D & N & A & SA \\
\hline $\begin{array}{l}\text { 1. I spend some time reading together with my } \\
\text { child(s). }\end{array}$ & $18.75 \%$ & $18.75 \%$ & $9.375 \%$ & $26.56 \%$ & $26.56 \%$ \\
\hline 2. I regularly buy books for my children. & $14.52 \%$ & $20.97 \%$ & $14.52 \%$ & $35.47 \%$ & $14.52 \%$ \\
\hline $\begin{array}{l}\text { 3. I spare my time to go through the students' } \\
\text { homework and what they have done in school. }\end{array}$ & $16.39 \%$ & $9.84 \%$ & $14.75 \%$ & $29.51 \%$ & $29.51 \%$ \\
\hline $\begin{array}{l}\text { 4. I offer incentives to my child for } \\
\text { encouragement to read more. }\end{array}$ & $11.48 \%$ & $21.31 \%$ & $11.48 \%$ & $22.95 \%$ & $32.78 \%$ \\
\hline $\begin{array}{l}\text { 5. I encourage the use of technology when } \\
\text { reading with my child. }\end{array}$ & $12.91 \%$ & $27.42 \%$ & $17.74 \%$ & $24.19 \%$ & $17.74 \%$ \\
\hline
\end{tabular}

Source: Primary data, 2021.

From the findings in the above table, over $50 \%$ of parents who participated in the study agreed that they spend some time reading together with the children, they go through 
students' homework and offer reading incentives to their children. Additionally, 49\% and $41 \%$ of parents did agree that they regularly buy books for their children and encourage the use of technology when reading with the child respectively. The findings also show that the parents who disagreed that they are engaged in their students learning process through various parental involvement practices ranged between $25 \%$ and $40 \%$. It was also noted from the findings that less than $20 \%$ of the parents did not have an idea rather remained neutral on various parental involvement practices. The findings generally show that over $50 \%$ of parents indeed engage in various parental involvement practices though there are some parents who still don't practice this. The findings support those of Felix (2017) in Nigeria who found that some parents are not engaged in their students learning process and could affect students' academic performance.

\subsubsection{Teachers' perception on parental involvement practices}

The researcher sought opinion of teachers who participated in the study on the level of involvement of parents in the learning process of their children. Through their interaction with students and the parents, teachers can have an idea on the level of parental involvement. The researcher presented to teachers various statements on parental involvement to assess their level of agreement. The scale of measurement was 1 to 5 where 1 represented strongly disagree (SD) and 5 represented strongly agree(SA). The findings were as presented in the following table.

Table 4: Teachers Perception on Parental Involvement Practices

\begin{tabular}{|l|c|c|c|c|c|}
\hline Parental involvement & SD & D & N & A & SA \\
\hline $\begin{array}{l}\text { 1. Parents donate books to the school library to } \\
\text { facilitate learning. }\end{array}$ & $11 \%$ & $20.32 \%$ & $5.52 \%$ & $28.56 \%$ & $30.60 \%$ \\
\hline $\begin{array}{l}\text { 2. Parents participate in prize giving to best } \\
\text { performing students in languages }\end{array}$ & $7.0 \%$ & $20.37 \%$ & $10.52 \%$ & $45.56 \%$ & $16.55 \%$ \\
\hline $\begin{array}{l}\text { 3. Parents ensure that the students do homework } \\
\text { given by teachers }\end{array}$ & $10.03 \%$ & $15.0 \%$ & $5.75 \%$ & $29.71 \%$ & $39.51 \%$ \\
\hline $\begin{array}{l}\text { 4. Parents donate teaching aids to school like } \\
\text { computers, projectors etc. }\end{array}$ & $4.05 \%$ & $13.50 \%$ & $11.55 \%$ & $32.05 \%$ & $38.85 \%$ \\
\hline $\begin{array}{l}\text { 5. Parents buy books recommended by } \\
\text { languages teachers for their children }\end{array}$ & $6.26 \%$ & $12.50 \%$ & $5.65 \%$ & $39.35 \%$ & $36.24 \%$ \\
\hline
\end{tabular}

Source: Primary data, 2021.

The table above show that $59 \%$ and $62 \%$ of teachers who participated in the study agreed that parents donate books to the school library and they attend prize giving day organized by school respectively while on the other side $31 \%$ and $27 \%$ respectively were of the opposite opinion. Additionally, over $70 \%$ of the teachers' respondents did indicate that parents buy books recommended by language teachers and they donate teaching aids to school like computers and projectors. However, $18 \%$ and $17 \%$ of teachers' respondents respectively were of a contrary opinion. Lastly the findings also did indicate that less than $12 \%$ of the teachers remained neutral to comment on various parental involvement practices. These results are an indication that a fairly big percentage of 
parents indeed engage in various parental involvement practices according to the teachers' opinions even though some parents are not actively involved. These findings are supported by Muigai (2018) and Mudaki (2016) who conducted their studies in Kenya and found that not all parents are involved in their students learning process.

\subsubsection{Students' perception on parental involvement practices}

The students are the direct beneficiaries of parental involvement and therefore their views are integral in this study. The researcher presented to students the various statements testing on the level of parental involvement on students learning process. The scale of measurement was from 1 to 5 where 1 denoted strong disagreement (SD) and 5 denoted strong agreement (SA). The findings were as shown in the following table.

Table 5: Students Perception on Parental Involvement Practices

\begin{tabular}{|l|c|c|c|c|c|}
\hline Parental involvement & $\mathbf{1}$ & $\mathbf{2}$ & $\mathbf{3}$ & $\mathbf{4}$ & $\mathbf{5}$ \\
\hline 1. We spend time reading together with my parent & 9.58 & 20.50 & 10.35 & 34.25 & 25.32 \\
\hline 2. My parent regularly buys for me story books to read. & 10.0 & 18.35 & 15.60 & 45.70 & 10.35 \\
\hline $\begin{array}{l}\text { 3. My parent goes through my homework and what we } \\
\text { have done in school }\end{array}$ & 5.70 & 18.35 & 10.05 & 50.45 & 15.45 \\
\hline $\begin{array}{l}\text { 4. My parent offers me various incentives as encouragement } \\
\text { to read. }\end{array}$ & 10.03 & 22.40 & 10.45 & 27.25 & 29.87 \\
\hline $\begin{array}{l}\text { 5. My parent provides me with technological devices for } \\
\text { reading such as computers and tablets. }\end{array}$ & 11.28 & 16.60 & 15.15 & 33.65 & 23.32 \\
\hline
\end{tabular}

Source: Primary data, 2021.

From Above, 56\% of the students did indicate that parents are engaged in various practices aimed at promoting learning. These include buying books for the child, going through the student homework, offering reading incentive, provision of technological devices to aid reading and reading together with the child. However, between $24 \%$ and $32 \%$ of students' respondents did indicate that their parents don't engage in various practices aimed at promoting learning. The findings also indicate that between $10 \%$ and $15 \%$ of students' respondents remained neutral on various parental involvement practices meaning they didn't know whether their parents are involved or not. These findings are not far from the opinions of teachers and parents earlier discussed which revealed that even though majority of parents are involved in their students learning, some still are yet to take the initiative.

An interview with the head teachers of the five schools of focus in this study revealed that indeed parents get involved in students learning process in a number of ways. The most commonly mentioned practices by the head teachers during the interview included buying books for the children and the donations to the school in terms of teaching aids and library resources, most parents are committed to attend meetings focusing on improving academic performance of their children such as prize giving, development of school infrastructure, performance appraisal for the teachers. The interview also revealed that from the class teachers reports, the head teachers indeed agreed that most parents follow up on the students' homework and what they have done 
at school, they also turn up without fail if they are called upon to solve some indiscipline cases among students among others. However, they stated that some parents are still not cooperative and this they cited being busy at work and some just ignorant at following their children work as causes.

According to the above findings on parental involvement practices, it's evident that parents get involved in their children' learning process in a number of ways such as buying books for reading for their children, attending school meetings, reading together with their children, going through homework given to their children, buying technological devices for their children to aid in learning among others. However, the involvement of parents on their students learning process is still moderate ranging $50 \%$ and above. these findings support Kutas statement that some parents engage in reading together with their children and support their children with books, attends school meetings and activities though some do not. This she argued is very helpful to the students leading outcomes as it improves students reading skills and act as a motivation to the student. (New Times, 2019). Additionally, the findings support those of Lara L. and Saracostti M. (2019) who found parental involvement in Chile to be medium at $48.5 \%$. Parental involvement at high level stood at $28.9 \%$ while parental involvement at low level was at $25.3 \%$. He explained that parents get involved in their students leaning through reading together with the child, going homework and practicing spelling together with the child, attends school meetings and special events, the students asks him/her to supervise the work and talk with the teacher, regularly receives calls from teachers regarding their children's schooling progress among others.

\subsubsection{Reading culture practices}

The second objective of this study involved identifying reading culture practices among students in secondary schools in Rwanda with a case of selected five schools. The researcher achieved this objective by seeking the views of students, parents and teachers.

\subsubsection{Students perception on reading culture practices}

The students were given questionnaire to fill and among the key areas of the questionnaire was the reading culture practices among students. The perception of students on various statements focusing on their reading culture was assessed on a scale of 1 to 5 where 1, 2, 3, 4, and 5 denoted strongly disagree(SD), Disagree(D), Neutral(N), Agree(A) and strongly agree(SA). The findings are summarized in the below table.

Table 6: Students Perception on Reading Culture Practices

\begin{tabular}{|l|c|c|c|c|c|}
\hline Students Reading culture & $\mathbf{1}$ & $\mathbf{2}$ & $\mathbf{3}$ & $\mathbf{4}$ & $\mathbf{5}$ \\
\hline 1. I have my favorite story books & $2.7 \%$ & $16.28 \%$ & $23.15 \%$ & $38.89 \%$ & $18.98 \%$ \\
\hline 2. most of my free time I spend reading books & $16 \%$ & $27.75 \%$ & $15.15 \%$ & $30.15 \%$ & $10.95 \%$ \\
\hline 3. I love and enjoy reading books & $10.05 \%$ & $30.65 \%$ & $11.15 \%$ & $30.15 \%$ & $18 \%$ \\
\hline $\begin{array}{l}\text { 4. I often share about the books i have read with } \\
\text { my fellow students }\end{array}$ & $10.1 \%$ & $33.1 \%$ & $11.75 \%$ & $17.25 \%$ & $27.8 \%$ \\
\hline
\end{tabular}




\begin{tabular}{|l|c|c|c|c|c|}
\hline \hline $\begin{array}{l}\text { 5. reading enhances my creativity and I always } \\
\text { write something about what I have read. }\end{array}$ & $10.45 \%$ & $14.35 \%$ & $20.50 \%$ & $19.42 \%$ & $35.28 \%$ \\
\hline $\begin{array}{l}\text { 6. I constantly consult from my teachers and my } \\
\text { parents for clarification on what I haven't } \\
\text { understood while reading. }\end{array}$ & $10.45 \%$ & $35.55 \%$ & $12.65 \%$ & $17.85 \%$ & $23.5 \%$ \\
\hline
\end{tabular}

Source: Primary data, 2021.

The researcher sought students' opinion on the level of their reading culture practices. From the findings, above $50 \%$ of students did agree that they have favorite story book and that reading enhances their creativity. However less than $50 \%$ of students agreed that they consult from parents, share the books they have read with fellow students, love and enjoy reading books and spend most of their free time reading books. Additionally, between $18 \%$ and $46 \%$ of students did disagree that they engage in various reading culture practices. lastly the findings also exhibit a significant percentage of students' participants who did not agree nor disagree in all the various reading culture practices presented to them accounting for over $10 \%$ but less than $25 \%$. These results indeed indicate that a significant percentage of students in the five schools of focus in this study do not have a good reading culture though a slight majority have.

\subsubsection{Parents Perception on students reading culture practices}

The questionnaire addressed to parents also assessed their level of agreement with various statements touching on students reading culture practices. The parents were to indicate whether they strongly agree (SD), disagree(D), Neutral(N), Agree(A) or strongly agree with the various statements presented to them. The findings are shown in the following table.

Table 7: Parents Perception on Students Reading Culture Practices

\begin{tabular}{|l|c|c|c|c|c|}
\hline Students Reading culture & $\mathbf{1}$ & $\mathbf{2}$ & $\mathbf{3}$ & $\mathbf{4}$ & $\mathbf{5}$ \\
\hline 1. My child has favorite story books & $6 \%$ & $30.12 \%$ & $15.23 \%$ & $38.45 \%$ & $10.2 \%$ \\
\hline 2. My child spend most of the time reading books & $10.9 \%$ & $30.25 \%$ & $14.85 \%$ & $22.5 \%$ & $21.5 \%$ \\
\hline 3. My child enjoy and love reading books & $21 \%$ & $18.8 \%$ & $20.5 \%$ & $26.7 \%$ & $13 \%$ \\
\hline $\begin{array}{l}\text { 4. My children and their friends often share about } \\
\text { the books they have read. }\end{array}$ & $10 \%$ & $11.5 \%$ & $24.95 \%$ & $40.5 \%$ & $13.05 \%$ \\
\hline $\begin{array}{l}\text { 5. reading has enabled my child to be creative and } \\
\text { loves writing on what he/she has read. }\end{array}$ & $10.6 \%$ & $21.45 \%$ & $17.85 \%$ & $32.65 \%$ & $17.45 \%$ \\
\hline $\begin{array}{l}\text { 6. My child often consult me for clarifications on } \\
\text { what she/he hasn't understood while reading. }\end{array}$ & $5 \%$ & $20.15 \%$ & $10.05 \%$ & $28.15 \%$ & 36.65 \\
\hline
\end{tabular}

Source: Primary data, 2021.

The findings above indicate that $48 \%$ and $43 \%$ of parents agreed respectively that their children have favorite story books and that they spend most of the time reading. Additionally, over $50 \%$ of parents did agree that their children share with their friends what they learnt, consults from them for clarifications and that reading has enabled their children to be creative and develop the love for writing on what they have read. However only $39.7 \%$ of parents did indicate that their children enjoy and love reading. The findings 
also indicate that over $30 \%$ of parents were of a contrary opinion in the cases of students having a favorite story book, child spending most of the time reading, child enjoying and loving reading and children' creativity enhancement through reading. On the other hand, $25.15 \%$ and $21.5 \%$ did disagree that their children consult them for clarifications and share with the friends about the books they have read respectively. It's also important to note that a significant percentage of parents' participants did remain neutral in all the circumstances without accepting or declining.

\subsubsection{Teachers perception on students reading culture practices}

Language teachers too have an idea on students reading culture since they interact with students more often and they are able to tell the reading culture of students. Therefore, the researcher tested the level of agreement of teachers with various statements on reading culture practices among students. This was done on a scale of 1 to 5 which denoted strongly disagree and strongly agree on respectively on the two ends and the findings presented in the below table.

Table 8: Teachers Perception on Students Reading Culture Practices

\begin{tabular}{|l|c|c|c|c|c|}
\hline Students Reading culture & $\mathbf{1}$ & $\mathbf{2}$ & $\mathbf{3}$ & $\mathbf{4}$ & $\mathbf{5}$ \\
\hline $\begin{array}{l}\text { 1. Students often talk about their favorite story } \\
\text { books. }\end{array}$ & $9.6 \%$ & $19.28 \%$ & $24.10 \%$ & $26.51 \%$ & $20.51 \%$ \\
\hline $\begin{array}{l}\text { 2. Students spend most of their free time } \\
\text { reading. }\end{array}$ & $16.25 \%$ & $28.75 \%$ & $18.75 \%$ & $20 \%$ & $16.25 \%$ \\
\hline 3. Students generally love reading books. & $10.84 \%$ & $25.3 \%$ & $14.46 \%$ & $26.51 \%$ & $22.89 \%$ \\
\hline $\begin{array}{l}\text { 4. Students often talk about the books they have } \\
\text { read. }\end{array}$ & $4.82 \%$ & $26.51 \%$ & $16.87 \%$ & $31.29 \%$ & $20.51 \%$ \\
\hline $\begin{array}{l}\text { 5. Students are creative enough and write } \\
\text { something about what they have read. }\end{array}$ & $6.17 \%$ & $18.52 \%$ & $27.16 \%$ & $27.16 \%$ & $20.99 \%$ \\
\hline $\begin{array}{l}\text { 6. Students actively consult from teachers for } \\
\text { clarification on what they haven't understood } \\
\text { while reading. }\end{array}$ & $5 \%$ & $27.5 \%$ & $21.25 \%$ & $26.25 \%$ & $20 \%$ \\
\hline
\end{tabular}

Source: Primary data, 2021.

Teachers also gave their opinion on the various reading culture practices among students. The findings indicated that the teachers who agreed that indeed students engage in various reading culture practices ranged between $36 \%$ and $51 \%$. On the other hand, the teachers who didn't agree that students engage in various reading culture practices ranged between $24 \%$ to $44 \%$. However, some teachers remained neutral rather did not know whether the students indeed engage in the various reading culture practices presented accounting for between $14 \%$ and $27 \%$. From the teachers' perception, it's evident that though students engage in various reading culture practices, there is still a significant number that don't according to teachers' opinion.

An interview with the head teachers of the five schools revealed a number of reading culture practices among students in their respective schools. The most commonly mentioned practices by the head teachers included reading story books by students, 
enjoying reading story books, students reading together in discussion forum, students spending their time in the library reading and ability of the student to remember and apply what they have read. However, it was noted from the interview that an average number of students in two schools and below average number in 3 schools have the reading culture motive. They pointed out that students nowadays fear reading books and this limits their knowledge ability and creativity and hence teachers are forced to adopt new and innovative teaching methods to ensure that the students perform for example use of pictorials in learning and constantly discussing with the students in class and giving them a lot of homework for them to understand better the content. They pointed out the growth of technology as a hindrance to students reading culture since they are carried away with so many activities in the internet where they like spending most of their time. Additionally, the head teachers also pointed out lack of parental involvement as a hindrance to reading culture. Three head teachers said that some parents are so busy with work and they don't have time to follow their children's education affairs. 'This leaves the teacher with a lot of work to do in order to ensure students excels in their studies', said one head teacher.

\subsubsection{Extent of parental involvement influence on students reading culture}

To have a general perception on the influence of parental involvement on students reading culture, the researcher gathered opinion of respondents including teachers, students and parents on the extent of parental involvement influence on reading culture among students. The scale of measurement was 1,2,3 which denoted no extent, small extent and large extent respectively. The findings are shown in the figure below.

Figure 1: Extent of parental involvement influence on students reading culture

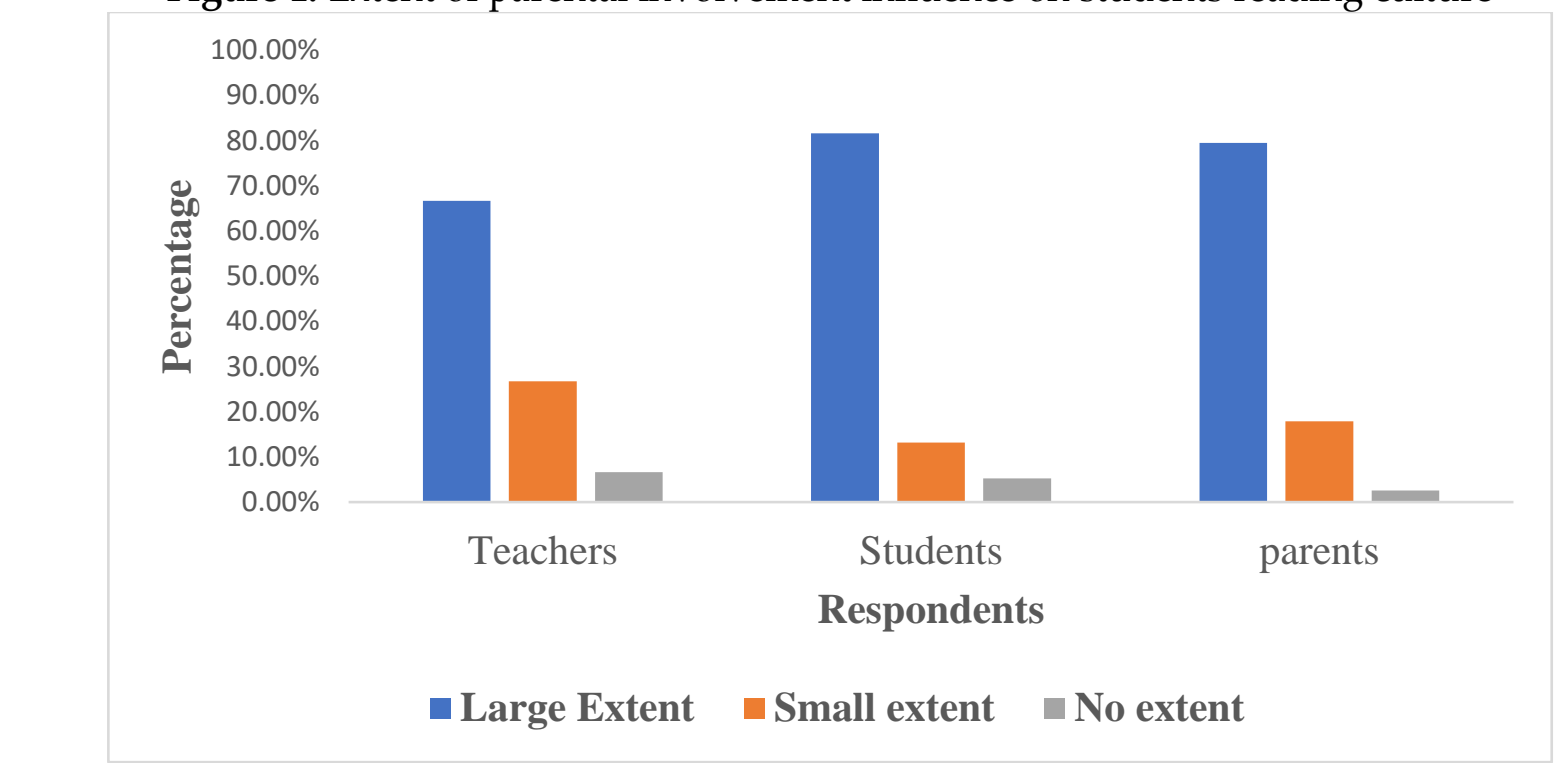

Source: Primary data, 2021.

The above figure shows that $66.7 \%, 81.6 \%$ and $79.5 \%$ of the teachers, students and parents respectively were of the opinion that parental involvement influence students reading 
culture to a large extent. Additionally, $26.76 \%, 13.2 \%$ and $17.9 \%$ of the teachers, students and parents respectively accepted that parental involvement influence students reading culture but to a small extent. Lastly the findings indicate that $6.6 \%, 5.2 \%$ and $2.6 \%$ of teachers, students and parents found no influence of parental involvement on students reading culture. Therefore, the results largely indicate that parental involvement indeed influences students reading culture.

From the interview with the head teachers of the four schools, they indicated that involvement of parents through participating in various activities and supports towards students learning is very crucial and to a large extent influences the students reading culture. They indicated that most of the top performers spend quiet good time reading and their parents are very strict in following their learning progress.

\subsection{Inferential findings}

\subsubsection{Correlation between parental involvement and reading culture among secondary students}

The researcher conducted correlation analysis between parental involvement and reading culture among students. This was achieved by computing the Pearson correlation coefficient. The findings are shown in the following table.

Table 9: Correlation between Parental Involvement and Students Reading Culture

\begin{tabular}{|l|l|c|c|}
\hline & & Parental involvement & Student reading culture \\
\hline Parental involvement & Pearson's Correlation & 1 & $.650^{* *}$ \\
\cline { 2 - 4 } & Sig. (2-tailed) & & .001 \\
\cline { 2 - 4 } & $\mathrm{N}$ & 288 & 288 \\
\hline \multirow{3}{*}{ Student reading culture } & Pearson's Correlation & $.650^{* *}$ & 1 \\
\cline { 2 - 4 } & Sig. (2-tailed) & .001 & 288 \\
\cline { 2 - 4 } & $\mathrm{N}$ & 288 & \\
\hline
\end{tabular}

Source: Primary data, 2021.

The findings in the above table shows that Pearson correlation coefficient is 0.65 and the significance level of 0 . 001. This indicates that there is a positive significant association between parental involvement and students reading culture. An improvement in parental involvement leads to an improvement in students reading culture and vice versa. This confirms the criticality of parental involvement on students reading culture. Parents play a key role in the learning process of their children not only in terms of fee payment but also getting involved in providing learning materials, spending time with the child and discuss education matters, making a follow up on the child's work and buying textbooks and digital learning aids to the child. This will ultimately lead to development of a positive reading culture by the child. According to Casey et al (2018), active support of the child's learning at home by the parent comes with benefits such as improved writing skills, language boost and reading achievement. This supports the idea that when a parent puts more efforts on his or her child's education, the benefits derived are positive in terms of improved reading and communication skills and literacy level. 


\subsubsection{Regression findings}

Regression findings involved computation of model summary, ANOVA and beta coefficients regarding parental involvement and reading culture among students. From the analysis the following tables summarizes the findings.

Table 10: Model Summary

\begin{tabular}{|c|c|c|c|}
\hline Model & R Square & Adjusted R Square & Std. Error of the Estimate \\
\hline 1 & .547 & .514 & .32785 \\
\hline
\end{tabular}

Source: Primary data, 2021.

The model summary table above shows that $\mathrm{R}$ square value is 0.547 equivalent to $54.7 \%$. This implies that parental involvement explains $54.7 \%$ of the variations in students reading culture other factors influencing reading culture among students explaining the remaining $45.3 \%$. This shows how important parental involvement is to the success of students reading culture.

Table 11: ANOVA

\begin{tabular}{|l|l|c|c|c|c|}
\hline \multicolumn{2}{|l|}{ Model } & Sum of Squares & df & F & Sig. \\
\hline \multirow{3}{*}{1} & Regression & 51.675 & 1 & 75.185 & $.000^{\mathrm{a}}$ \\
\cline { 2 - 5 } & Residual & 23.356 & 97 & & \\
\cline { 2 - 5 } & Total & 75.031 & 98 & & \\
\hline \multicolumn{2}{|l|}{ Dependent Variable: Students reading culture } & & \\
\hline
\end{tabular}

Source: Primary data, 2021.

The Analysis of Variance shows the appropriateness of the model used to link the dependent variable and the independent variables. The ANOVA table presented above indicates that F statistics value is 75.185 which is fairly high and the significance value is 0.000. This implies that linear regression model fit presented in chapter three is very appropriate in explaining the relationship between parental involvement and reading culture among students.

Table 12: Model Coefficients

\begin{tabular}{|c|c|c|c|c|c|}
\hline \multirow{2}{*}{\multicolumn{2}{|c|}{ Model }} & \multicolumn{2}{|c|}{ Unstandardized Coefficients } & \multirow{2}{*}{$\mathbf{t}$} & \multirow{2}{*}{ Sig. } \\
\hline & & B & Std. Error & & \\
\hline \multirow[t]{2}{*}{1} & (Constant) & .312 & .132 & .228 & .000 \\
\hline & Parental involvement & .119 & .058 & 6.730 & .025 \\
\hline \multicolumn{3}{|c|}{ Dependent Variable: Students reading culture } & & & \\
\hline
\end{tabular}

Source: Primary data, 2021.

The beta coefficients table above shows that the constant term has a coefficient of 0.312 and a significance of 0.000 . The independent variable in this study which is parental involvement has a coefficient of 0.119 and significance of 0.025 . From this information, 1 $\%$ change in parental involvement leads to $11.9 \%$ proportionate change in students reading culture keeping other factors constant. The significance value for parental 
involvement is 0.025 which is less than 0.05 . Therefore, there is a positive significant influence of parental involvement on students reading culture.

These findings are in concurrence with the findings of Mudaki (2016) in Kenya who found that parental involvement is very critical in enhancing students reading comprehension skills. In addition, Ruterana (2012) in Rwanda also opined that lack of reading materials could also cause poor reading culture. Reading material such as text books and technological devices like computers provided by the parent help boost students reading culture. The authors recommended more libraries be set up and be well resourced in addition to organizing workshops to provide parents with knowledge on education matters and their role in enhancing good reading culture among their children. Other authors like Muigai (2018) in Kenya also stressed the importance of parental involvement in enhancing reading skills among students and Juma C. \& Mpoki M. (2012) in Tanzania who stressed the contribution of parental support in enhancing student's numeracy and reading skills. These previous literatures from other countries indeed indicate that parental involvement is integral in promoting good reading culture among students. Rwanda's case which focuses on causes of poor reading culture also cites lack of resources hence the need to have well-resourced education institutions and national libraries where students are able to easily access the materials to read and boost their reading skills.

\section{Conclusion and Recommendations}

\subsection{Conclusion}

The researcher came up with a number of conclusions from the above findings.

First, parents are involved in various activities in the learning process though to a moderate extent. The key practices that parents involve in include donating books and teaching aids to school, buying recommended books for their children, reading together with their children, spending time reading, going through students' homework, offering technological support in reading to their children, offering reading incentives to their children and participating in prize giving occasions in school. However, this study notes that not all parents participate in their students learning process.

Secondly, the study concludes that good reading culture is practiced to a moderate extent among secondary school students. Some students have a good reading culture practice while others have poor culture of reading. This study notes that the key reading culture practices among students included having a favorite story book, spending free time reading, love for reading, making consultations from parents and teachers for clarifications, sharing what they have read with the friends and being creative and writing something on what they have read.

Lastly, this study concludes that there is a strong positive significant association between parental involvement and students reading culture. Parental involvement has a significant positive influence on students reading culture. An improvement in parental involvement leads to an improvement in students reading culture. 


\subsection{Recommendation}

From the conclusions above, first the study recommends the need to enhance parental involvement in students learning process for improved reading culture in schools. Parents should spend some time reading together with their children to know the progress of their children, they should support the children in terms of buying them recommended books by teachers and also providing them with some teaching aids like computers but being cautious and making a follow up to ensure that such devices are indeed used for learning not for other activities like playing games and listening to music. Parents should also ensure that their children do the homework given by teachers, they provide reading incentives to their children and attend various academic meetings organized by school involving the parents. This will enable them to get in touch with other school stakeholders and ensure a smooth learning process for their children which ultimately motivates their children to read more and perform well.

The study recommends that school administrators organize workshops and meetings for parents to be taught on how to engage on students learning so as to improve the reading culture and performance of their children. Parents should be made aware that the success of their children does not only depend on the teachers' efforts, but they also play a key role hence they should be greatly involved beyond just meeting their fee payment obligations. Additionally, school administrators should ensure that the library is well resourced with reading materials for accessibility by the student. This will also encourage the students to develop a positive attitude towards reading.

Teachers on the other hand should always make a follow up with the parent to make sure that indeed parents help their kids in doing homework and providing reading materials in order to encourage a positive reading attitude on students. Teachers should also be on the forefront to encourage students to develop a culture of reading by sending them to the library to search for some reading materials and read.

\section{Conflict of Interest Statement}

The authors declare no conflicts of interests.

\section{About the Author}

Dr. Andala Hesbon is a PhD holder in Education, planning and policy analysis from Open University of Tanzania. He has a wide experience in teaching of over 30 years both at secondary and university level in Kenya and Rwanda. He has held various positions in his teaching carrier notably head of department, games coach and dean of faculty. He is currently the acting dean in the school of education Mount Kenya University Rwanda. His main areas of interest include educational measurement and evaluation, educational planning and policy analysis

Mr. Davis Otieno holds bachelor's degree in Education from Mount Kenya University. He has a wide experience in teaching both in primary, secondary and college level. He is currently teaching at Acorns International school in Rwanda and part time lecturing at Adventist University of Central Africa Rwanda. His main area of interest is languages. 


\section{References}

Bartel V. (2010). Home and School Factors Impacting Parental involvement in a title Elementary school. Journal of Research in Childhood Education, 209-228.

Dang A. H. and Rogers F. H. (2008). The growing phenomenon of private tutoring : does it deepen human capital, widen inequalities, or waste resources? World Bank Research Observer, Vol 23 no 2.

Evans W. (2018). Investigating Reading Culture Among students in Higher learning Institutions in Tanzania. University of Dar es Salam.

Felix R. (2017). Influence of Parental Engagement with schools and students on academic performance in Nigeria. European Scientific Journal, 113-119.

Fiore C. and Roman S. (2010). Proof Positive. School Library Journal, 26-29.

Fredrick O. (2011). Reading Culture, cultivation and its Promotion among Pupils: a Kenyan Perspective. International Research Journal of Library, Information and Archival Studies Vol. 1(1) pp. 001-005,

Hornby G. and Lafaele R. (2011). Barriers to Parental Involvement in Education. An Explanatory model. Educational Review, 37-52.

Juma C. and Mpoki M. (2012). The Influence of Parental Support on Childs Learning of Literacy in Tanzania. Dar es Salam: University of Dar es Salam.

Kothari C. R. (2008). Research Methodology: Methods and Techniques. New Delhi: New Age International.

Kothari C. R. (2010). Research Methodology. Methods and Techniques. New Delhi: New Age International.

Larocque et al. (2011). Parental Involvement: The Missing Link in School Achievement. Preventing School Failure, 115-122.

Lara L. and Saracostti M. (2019). Effect of Parental Involvement on Children's Academic Achievement in Chile. Front. Psychol. 10:1464. doi: 10.3389/fpsyg.2019.01464

Mamta et al (2018). The Role of Parental Involvement and Social Emotional Skills in Academic Achievement: Global Perspective. School Community Journal, Vol 28 No 2.

Monica et al. (2015). Assessment of Possible Causes of poor reading culture of secondary school students in Ugunja District, Siaya County, Kenya. International Journal of Educational Policy Research and Review, 60-68.

Mudaki J. (2016). Influence of Parental Involvement on Performance of Children aged 5-6 Years in Kiswahili Reading Comprehension in Public Pre-Schools in Athi River Zone, Machakos County. Nairobi: University of Nairobi.

Muigai J. (2018). Parental Involvement in Primary Schools in Kenya as a major strategy for academic success. European Journal of Educational Studies, vol 5 issue 3.

Nelson Royes A. M. (2013). Tutors Can Improve Students Reading Skills . Reading Improvement, 48-53.

Ruterana Pierre (2012). Developing A Culture of Reading in Rwanda. Linkoping: Linkoping University. 
Stephen W. (2012). Impact of Extra Curricular Activities on student Achievement at the High School Level. Mississippi: University of Southern Mississippi.

Vellymalay S.K (2012). Parental Involvement at Home: Analysing the Influence of Parents socioeconomic status. Studies in Sociology of Science, 1-6.

Whitaker M. and Hoover K. (2013). School Influences on Parents Role Beliefs. The Elementary School Journal, 73-99. 

to copy, distribute, transmit or adapt the article content, providing a proper, prominent and unambiguous attribution to the authors in a manner that makes clear that the materials are being reused under permission of a Creative Commons License. Views, opinions and conclusions expressed in this research article are views, opinions and conclusions of the author(s). Open Access Publishing Group and European Journal of Education Studies shall not be responsible or answerable for any loss, damage or liability caused in relation to/arising out of conflicts of interest, copyright violations and inappropriate or inaccurate use of any kind content related or integrated into the research work. All the published works are meeting the Open Access Publishing requirements and can be freely accessed, shared, modified, distributed and used in educational, commercial and non-commercial purposes under a Creative Commons Attribution 4.0 International License (CC BY 4.0). 